\title{
Editorial
}

\section{Caspases: A decade of death research}

\author{
NA Thornberry ${ }^{\star, 1}$ \\ ${ }^{1}$ Department of Enzymology and Protein Biochemistry, Merck Research \\ Laboratories, R80M-103, P0 Box 2000, E. Lincoln Ave., Rahway, New Jersey \\ 07065, USA \\ * Corresponding author: NA Thornberry; Tel: +1 732-594-7120; \\ Fax: +1 732-594-3664; E-mail: nancy@merck.com \\ Edited by G Melino
}

As the end of the millenium approaches, we reflect on the monumental advances in cell biology that have been achieved, particularly in the last 50 years. Consider that proteins were first found to have precise amino acid sequences in 1953 by Sanger, about the same time that Watson and Crick deduced the three-dimensional structure of DNA. In this context, it seems remarkable that we now have such an intimate understanding of at least some basic cellular mechanisms, thanks largely to relatively recent advances in genomics, molecular biology, and in vitro techniques for the study for protein structure and function. Nowhere is rapid progress more evident than in the field of apoptosis, where the basic framework of this process has been defined at the molecular level in only the past 10 years (see Figure 1).

In 1990, apoptosis was known to be a form of cell death distinct from necrosis, involving a characteristic set of morphological changes and DNA fragmentation. ${ }^{1}$ Although a number of genes had been implicated in cell death in Caenorhabditis elegans, their biochemical functions, and the degree to which these mechanisms were conserved in mammals, were completely unknown. At about the same time, investigators in a seemingly unrelated area, inflammation, were engaged in the study of pro-lL- $1 \beta$ processing, in the hope that identification of the responsible protease would provide a starting point for the development of new therapeutic agents. This work led to the discovery of a novel protease, interleukin-1 $\beta$ converting enzyme (ICE), now known as caspase-1. ${ }^{2,3}$ The connection between caspases and apoptosis was made late in 1993 when Junying Yuan and her colleagues reported that caspase-1 is related to a Caenorhabditis elegans death gene, CED-3. ${ }^{4}$ This work not only reinforced the prevailing view that molecular mechanisms of cell death were highly conserved, but established proteases, caspases in particular, as key mediators of this process.

This seminal finding led to an explosion of interest in these enzymes, which has resulted in what is probably a fairly accurate view of the fundamental mechanisms they employ to kill cells. The details are far from clear, however, particularly concerning strategies that cells use to regulate this process. As the end of the first decade of caspase research approaches, it seems an opportune time to review the current thinking regarding the roles of these enzymes in cell death, and summarize some of the challenges that remain for future research in this area.

\section{Caspases and cell death}

As described in the overview of caspase structure and function by Nicholson, there are currently 11 human caspases. The precise biological functions of several of these enzymes remain to be established, but it is clear that they play pivitol and distinct roles in both inflammation and apoptosis, raising intriguing questions as to the evolutionary relationships between these processes. The structural and in vitro biochemical properties of these proteases are well understood; on several counts, these enzymes are perfectly engineered to implement the highly coordinated and regulated events of apoptosis.

For example, the well ordered and specific cleavages of proteins that are required to mediate apoptosis require a proteolytic machinery that is highly discriminatory. In fact, caspases are among the most selective of proteases, with a stringent specificity for cleavage after aspartic acid. The Nicholson review includes the most comprehensive list of identified endogenous substrates for caspases to date. From work in this area, it is now clear that a number of different strategies are employed to kill cells, including dissembly of cellular structures, deregulation of homeostatic processes, and inactivation of apoptosis inhibitors.

The review on catalytic properties of caspases, by Stennicke and Salvesen, serves as a reminder that, fundamentally, caspases are proteases, and have many of the structural and functional characteristics of other protease family members. For example, like other proteases, caspases are synthesized as zymogens that require limited proteolysis to produced the mature enzymes found in apoptotic cells. Likewise, it is now clear that these zymogens are activated in cascades that are clearly reminiscent of protease cascades found in other biological systems.

As described in the review on caspase cascades by Slee, Adrain and Martin, the currently held view is that initiator caspases proteolytically activate effector caspases, which in turn employ the strategies described above to dismantle the cell (Figure 2). Recent data by the authors, however, suggest that the story is not so simple, and that effector caspase maturation is followed by activation of other caspases (including some previously believed to function only as initiators) during an amplification phase of cell death. The notion that caspase cascades contain amplification pathways provides an attractive rationale for the rapid onset of apoptosis that is observed under some conditions. However, a cautionary note should be added, in that the molecular ordering of caspases as presented in the 
review is derived largely from in vitro studies; clearly, more work is required to understand the sequence of events that occurs in vivo.

How are initiator caspases activated? As summarized by Kumar, it appears that these enzymes employ an 'induced proximity' model of activation in which proenzyme oligomerization, mediated by specific auxiliary proteins, results in activation by intermolecular autoproteolysis. While there is good evidence for this model, the precise molecular basis for zymogen activation remains a complete mystery. It is likely that some of the paradigms established for other proteases will apply here; ${ }^{5}$ however, the definitive resolution of this question will almost certainly require a threedimensional structure of a caspase zymogen.

The existence of caspase cascades, and their importance in apoptosis, has been elegantly confirmed by targeted gene disruption experiments, as described in the review by Flavell and colleagues, and in the description of the Apaf1 knockout by Cecconi. Work with cells from these animals has also definitively established that different pathways are triggered by distinct pro-apoptotic signals.

Most unexpected were the remarkably tissue-specific phenotypes of caspase deficient animals, despite the presence of multiple caspases in these tissues. This, together with the observation that different phenotypes are observed with caspase knockouts and animals that are lacking in their corresponding regulatory proteins (eg.
Apaf1/caspase-9, Fas/caspase-8), and the finding that at least some phenotypes are strain-specific, indicates that there is still much to learn about the function and cellular (and sub-cellular) distributions of individual caspases and their regulators.

To make matters even more complicated, there is increasing evidence that caspase-independent pathways of cell death exist, and also that caspases may have functions in addition to their well-established roles in inflammation and apoptosis. The latter is described in the review by De Maria and colleagues. Particularly surprising are accounts that caspase-3, the prototypical pro-apoptotic caspase, is activated in cells in the absence of detectable cell death. Although more work is required to confirm that observation (particularly given the difficulties associated with stabilizing caspase zymogens past cell lysis), it raises the question of when commitment to death occurs, and reminds us that cells go to extraordingy lengths to protect themselves from accidental apoptosis.

In this regard, caspase regulation is clearly one of the most poorly understood facets of apoptosis. Regulatory molecules include apaptor proteins, decoy enzymes, and direct inhibitors. Other potential mechanisms of regulation for which there is evidence include phosphorylation, nitrosylation, and compartmentalization. As described in the review on caspase inhibitors by Vaux and colleagues, the IAP proteins are the only known endogenous

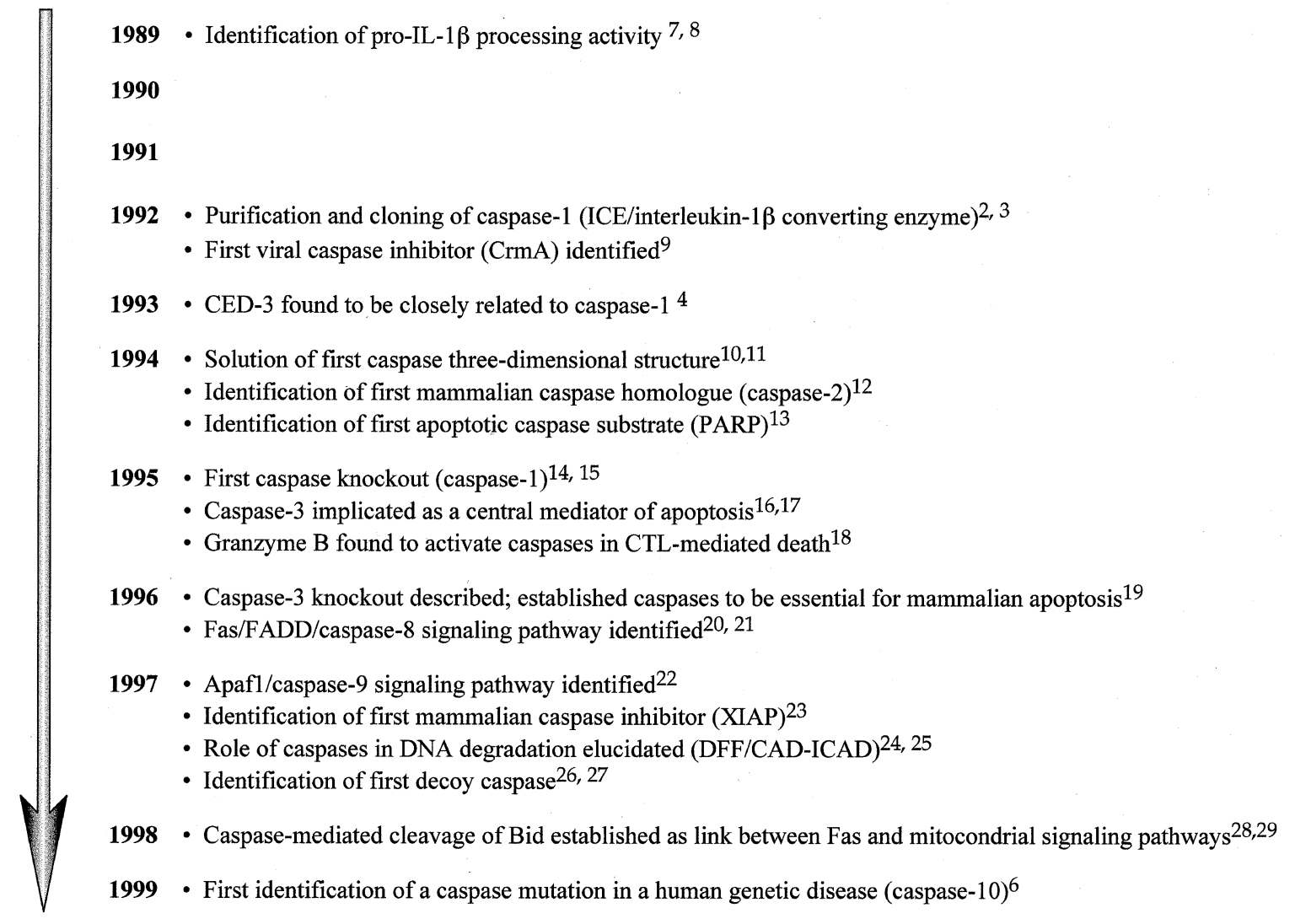

Figure 1 Milestones in caspase research 
mammalian caspase inhibitors. Conversely, several classes of viral inhibitors have evolved to facilitate infection. No doubt, some of the redundant death pathways that exist in certain situations (e.g. CTL-mediated killing) have evolved to cope with these pesky viruses, reminiscent of a game of cat and mouse.

\section{Challenges for future research}

Although caspase regulation remains one of the ripest areas for future research, there are many other formidable challenges. Studies with caspase knockouts have only begun to reveal the complexities of the pathways that exist in different cells and tissues during development. Virtually nothing is known of the caspase pathways that are utilized in fully differentiated organisms. The redundancy that is sure to exist in some cases is a further complicating feature.
Yet another layer of complexity was recently revealed by Lenardo and colleagues, who have found that individuals with a severe autoimmune lymphoproliferative disorder (ALPs Type II) have a defect in caspase-10. ${ }^{6}$ Surprisingly, Fas signaling is attenuated in lymphocytes from these patients, despite the presence of caspase-8. This raises the fascinating possibility that signaling by death receptors may require the formation of mixed heterodimers of caspase-8 and capase-10.

At present, the issue of how cleavage of caspase substrates results in most of the biochemical and morphological changes that are observed is relatively unclear. As described in the Nicholson review, Sahara et al. have recently identified the protein that appears to be required for chromatin condensation, using a combination of solid biochemistry and antisense techniques. This study serves as a nice example of the kind of approaches that

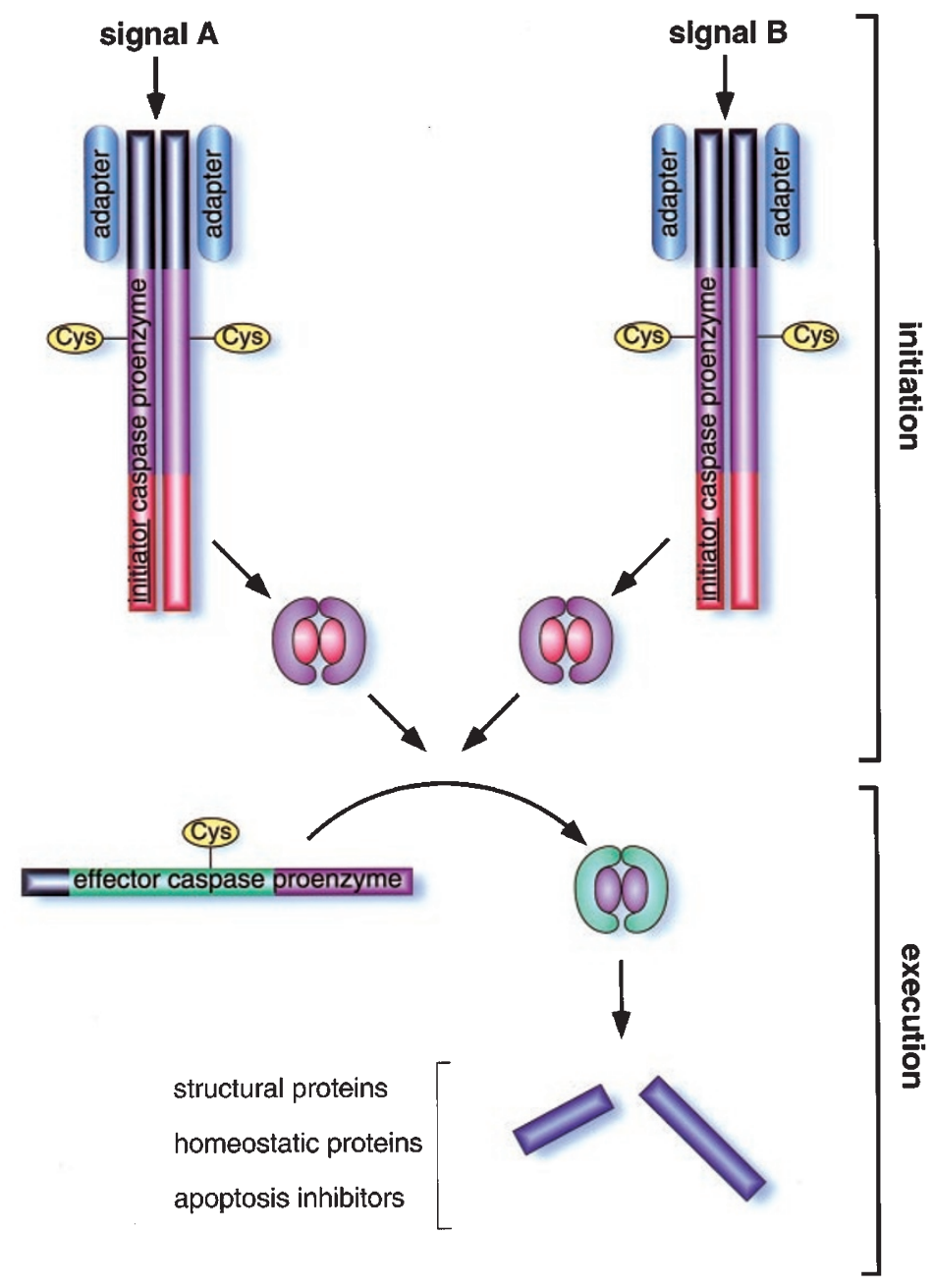

Figure 2 Caspase cascades mediate the initiation and execution of cell death. Pro-apoptotic signals trigger the recruitment of initiator caspase proenzymes to multiprotein complexes with specific adaptor proteins. The 'induced promixity' of caspase proenzymes in these complexes is believed to result in activation via intermolecular autoproteolysis. The mature enzymes activate effector caspases which, in turn, cleave a large number of structural, homeostatic, and regulatory proteins, resulting in cellular disassembly 
are required to definitively establish the functions of individual caspase substrates in apoptosis. Gene knock-in techniques with putative caspase substrates in which the cleavage sites are mutated should also prove enlightening.

An understanding of the role of the mitochondrion in cell death remains elusive. Likewise, the mechanisms involved in clearance of apoptotic material are a complete enigma. It is likely that studies in lower organisms that are amenable to genetic manipulation will continue to provide insights into some of these areas. Advances in understanding will require continued evaluation and confirmation of existing models with genetics, quantitative biochemistry, and an open mind.

\section{Therapeutic prospects}

A link between dysregulation of apoptosis and disease in humans has been clearly established. For example, there is excellent genetic evidence that insufficient cell death results in cancer (p53 defects) and lymphoproliferative disorders (caspase-10 mutations). Conversely, excessive cell death has been genetically linked to spinal muscular atrophy (NAIP), and is believed to be a contributing factor in neurodegenerative disorders, trauma, and stroke, to name a few. Indeed, peptide-based caspase inhibitors have been shown to be effective in several animal models of disease, although one should be careful not to attribute too much significance to these observations, given the promiscuous nature of these inhibitors.

Although it is firmly established that dysregulation of apoptosis can be harmful, it is much less clear what to do about it. Selective induction of apoptosis for treatment of cancer will clearly require a better understanding of the death pathways that exist in normal and transformed cells. One potential strategy that has recently received some attention involves selective induction of apoptosis in the endothelial cells that feed tumors, although questions remain about the utility of this approach as a single line of therapy.

On the face of it, attenuation of excessive cell death via caspase inhibition seems more promising in the short run, at least for acute therapy. Good progress has been made recently toward the identification of caspase inhibitors with improved properties for use in vivo. The most significant issue is a clinical one: will delayed administration of a caspase inhibitor be therapeutically effective? The results reported so far in animal models look promising, but experiments with more selective inhibitors are required.

Treatment of chronic diseases that may result from excessive apoptosis is a different story entirely. Such therapy will require selective inhibitors with excellent cell penetration and good (and preferably oral) bioavailability, not a trivial task in the area of protease inhibition. Selection of a suitable target caspase will, once again, require an excellent understanding of the caspase pathways that exist in normal and diseased states. Nonetheless, if progress in the past ten years is any measure of what is to come in the field of apoptosis, it seems certain that research in the near future will results in answers to many of these questions.

\section{References}

1. Ellis RE, Yuan J and Horvitz HR (1991) Mechanisms and functions of cell death. Annu. Rev. Cell Biol. 7: 663-698

2. Cerretti DP, Kozlosky CJ, Mosely B, Nelson N, Van Ness K, Greenstreet TA, March CJ, Kronheim SR, Druck T, Cannizzaro LA, Huebner K and Black RA (1992) Molecular cloning of the interleukin- $1 \beta$ converting enzyme. Science 256 : $97-100$

3. Thornberry NA, Bull HG, Calaycay JR, Chapman KT, Howard AD, Kostura MJ, Miller DK, Molineaux SM, Weidner JR, Aunina J, Elliston KO, Ayala JM, Casano FJ, Chin J, Ding GJ-F, Egger LA, Gaffney EP, Limjuco G, Palyha OC, Raju SM, Rolando AM, Salley JP, Yamin T-T, Lee TD, Shively JE, MacCoss M, Mumford RA, Schmidt JA and Tocci MJ (1992) A novel heterodimeric cysteine protease is required for interleukin- $1 \beta$ processing in monocytes. Nature 356: $768-774$

4. Yuan J, Shaham S, Ledoux S, Ellis HM and Horvitz HR (1993) The C. eleganscell death genes ced-3 encodes a protein similar to mammalian interleukin- $1 \beta$ converting enzyme. Cell 75: 641-652

5. Khan AR and James MNG (1998) Molecular mechanisms for the conversion of zymogens to active proteolytic enzymes. Protein Sci. 7: 815-836

6. Wang J, Zheng L, Lobito A, Chan FK-M, Dale J, Sneller M, Yao X, Puck JM, Strauss SE and Lenardo MJ (1999) Inherited human caspase 10 mutations underlie defective lymphocyte and dendritic cell apoptosis in autoimmune lymphoproliferative syndrome Type II. Cell 98: 47-58

7. Black RA, Kronheim SR and Sleath PR (1989) Activation of interleukin- $1 \beta$ by a co-induced protease. FEBS Lett. 247: 386-390

8. Kostura MJ, Tocci MJ, Limjuco G, Chin J, Cameron P, Hillman AG, Chartrain NA and Schmidt JA (1989) Identification of a monocyte specific pre-interleukin $1 \beta$ convertase activity. Proc. Natl. Acad. Sci. U.S.A. 86: 5227-5231

9. Ray CA, Black RA, Kronheim SR, Greenstreet TA, Sleath PR, Salvesen GS and Pickup DJ (1992) Viral inhibition of inflammation: Cowpox virus encodes an inhibitor of the interleukin-1 $\beta$ converting enzyme. Cell 69: 597-604

10. WalkerNPC, Talanian RV, Brady KD, Dang LC, Bump NJ, Ferenz CR, Franklin S, Ghayur T, Hackett MC, Hammill LD, Herzog L, Hugunin M, Houy W, Mankovich JA, McGuinness L, Orlewicz E, Pasking M, Pratt CA, Reis P, Summani A, Terranova M, Welch JP, Xiong L, Moller A, Tracey DE, Kamen R and Wong WW (1994) Crystal structure of the cysteine protease interleukin-1 $\beta$-converting enzyme: A (p20/p10) 2 homodimer. Cell 78: 343-352.

11. Wilson KP, Black JF, Thomson JA, Kim EE, Griffith JP, Navia MA, Murcko MA, Chambers SP, Aldape RA, Raybuck SA and Livingston DJ (1994) Structure and mechanism of interleukin-1 $\beta$ converting enzyme. Nature 370: 270-275

12. Wang L, Miura M, Bergeron L, Zhu H and Yuan J (1994) Ich-1, an Ice/ced-3related gene, encodes both positive and negative regulators of programmed cell death. Cell 78: 739-750

13. Lazebnik YA, Kaufmann SH, Desnoyers S, Poirier GG and Earnshw WC (1994) Reconstitution of the apoptotic cascade in vitro: Pivotal role for prICE, a protease resembling interleukin-1 $\beta$ converting enzyme and demonstration that poly(ADP ribose) polymerase is a substrate for this enzyme during apoptosis. Nature 371 : $346-347$

14. Kuida K, Lippke JA, Ku F, Harding MW, Livingston DJ, Su, MS-S and Flavell RA (1995) Altered cytokine export and apoptosis in mice deficient in interleukin-1 $\beta$ converting enzyme. Science 267: 2000-2003

15. Li P, Allen H, Banerjee S, Franklin S, Herzog L, Johnson C. McDowell J, Paskind M, Rodman L, Salfeld J, Towne E, Tracey D, Wardwell S, Wei F-Y, Wong W, Kamen $R$ and Seshadri T (1995) Mice deficient in IL-1 $\beta$-converting enzyme are defective in production of mature IL-1 $\beta$ and resistant to endotoxic shock. Cell 80 : 401-411

16. Nicholson DW, Ali A, Thornberry NA, Vaillancourt JP, Ding CK, Gallant M, Gereau Y, Griffin PR, Labelle M, Lazebnik YA, Munday NA, Raju AM, Smulson ME, Yamin T-T, Yu VL and Miller DK (1995) Identification and inhibition of the ICE/CED-3 protease necessary for mammalian apoptosis. Nature 376: 37-43

17. Tewari M, Quan LT, O'Rourke K, Desnoyers S, Zeng Z, Beidler DR, Poirier GG, Salvesen GA and Dixit VM (1995) Yama/CPP32 $\beta$, a mammalian homolog of CED-3, is a CrmA-inhibitable protease that cleaves the death substrate poly(ADP-ribose) polymerase. Cell 81: 801-809

18. Darmon AJ, Nicholson DW and Bleackley RC (1995) Activation of the apoptotic protease CPP32 by cytotoxic T-cell-derived granzyme B. Nature 377: 446-448

19. Kuida K, Zheng TS, Na S, Kuan C, Yang D, Karasuyama H, Rakic $P$ and Flavell RA (1996) Decreased apoptosis in the brain and premature lethality in CPP32deficient mice. Nature 384: $368-372$ 
20. Boldin MP, Goncharov TM, Goltsev YV and Wallach D (1996) Involvement of $\mathrm{MACH}$, a novel MORT1/FADD-intereacting protease, in Fas/APO-1 and TNF receptor-induced cell death. Cell 85: 803-815

21. Muzio M, Chinnaiyan AM, Kischkel FC, O'Rourke K, Shevchenko A, Ni J, Scaffidi C, Bretz JD, Zhang M, Gentz R, Mann M, Krammer PJ, Peter ME and Dixit VM (1996) FLICE, a novel FADD-homologous ICE/CED-3-like protease, is recruited to the CD95 (Fas/APO-1) death-inducing signaling complex. Cell 85: 817-827

22. Li P, Nijhawan D, Budihardjo I, Srinivasula SM, Ahman M, Alnenri ES and Wang $X$ (1997) Cytochrome $C$ and dATP-dependent formation of Apaf-1/caspase- 9 complex initiates an apoptotic protease cascade. Cell 91: 479-489

23. Deveraux QL, Takahashi R, Salvesen GS and Reed JC (1997) X-linked IAP is a direct inhibitor of cell-death proteases. Nature 388: $300-304$

24. Liu XS, Zou H, Slaughter C and Wang XD (1997) DFF, a heterodimeric protein that functions downstream of caspase-3 to trigger DNA fragmentation during apoptosis. Cell 89: 175-184
25. Enari M, Satahira H, Yokoyena H, Otawe K, Iwamatsu A and Nagata S (1998) A caspase-activated DNase that degrades DNA during apoptosis, and its inhibitor ICAD. Nature 391: 43-50

26. Shu H-B, Halpin DR and Goeddel DV (1997) Casper is a FADD- and caspaserelated inducer of apoptosis. Immunity 6: 751-763

27. Irmler M, Thorne M, Hahne M, Schneider P, Hofmann K, Steiner V, Bodmer J-L, Schroter M, Burns K, Mattmann C, Rimoldi D, French LE and Tschopp J (1997) Inhibition of death receptor signals by cellular FLIP. Nature 388: 190-195

28. LiH, Zhu H, Xu C-J and Yuan J (1998) Cleavage of BID by caspase 8 mediates the mitochondrial damage in the Fas pathway of apoptosis. Cell 94: 491-501

29. Luo X, Budihardjol,Zou H. Slaughter C and Wang X (1998) Bid, a Bcl2 interacting protein, mediates cytochrome $c$ release from mitochrondria in response to activation of cell surface death receptors. Cell 94: 481-490 